\title{
The Size and Growth of Microfinance Institutions
}

\author{
José Liñares-Zegarra ${ }^{\mathrm{a}}$
}

John O. S. Wilson ${ }^{\mathrm{b}}$

\begin{abstract}
We investigate the relationship between size (measured by total assets and number of active borrowers) and growth for a worldwide sample of microfinance institutions with different ownership forms (micro-banks, NGOs, cooperatives/credit unions, and non-bank financial institutions) and commercial orientation (profit and not-for-profit) drawn from 120 countries over the period 2000 to 2014. Using a dynamic panel data model, we find little evidence that size confers growth advantages to microfinance institutions. We find some evidence that growth rates for credit unions and microfinance institutions with a not-for-profit commercial orientation present negative persistence. The variability of growth rates differ across the size distribution of microfinance institutions and this result is consistent across commercial orientation and ownership form. Other factors affecting the growth of microfinance institutions include age (new microfinance institutions grow faster than young and mature counterparts), levels of bad debt, efficiency and regulation.
\end{abstract}

Keywords: Gibrat's law; growth; microfinance; outreach; persistence

JEL Classification: G21; G32; L25

\footnotetext{
${ }^{a}$ Essex Business School, University of Essex, Wivenhoe Park, Colchester, CO4 3SQ, UK, UK. Tel: +44 (0)1206 873072, Fax: +44 (0)1206 873429, Email: jmlina@essex.ac.uk

${ }^{\mathrm{b}}$ Centre for Responsible Banking \& Finance, School of Management, University of St Andrews, St Andrews, Scotland, KY16 9SS, UK. Tel: +44 (0)1334 462800, Fax: +44 (0)1334 462812, Email: jsw7@st-andrews.ac.uk
}

Acknowledgements: Financial support from the Research Committee Funds - Essex Business School (EBS) is gratefully acknowledged by the authors. Lili Yan provided excellent research assistance collecting and preparing the microfinance data for analysis. We are also grateful to the participants at the Public Services and Charities: Accounting, Accountability and Governance at a Time of Change Conference, which took place at the Queen's University of Belfast in January 2017. 


\title{
The Size and Growth of Microfinance Institutions
}

\begin{abstract}
We investigate the relationship between size (measured by total assets and number of active borrowers) and growth for a worldwide sample of microfinance institutions with different ownership forms (micro-banks, NGOs, cooperatives/credit unions, and non-bank financial institutions) and commercial orientation (profit and not-for-profit) drawn from 120 countries over the period 2000 to 2014. Using a dynamic panel data model, we find little evidence that size confers growth advantages to microfinance institutions. We find some evidence that growth rates for credit unions and microfinance institutions with a not-for-profit commercial orientation present negative persistence. The variability of growth rates differ across the size distribution of microfinance institutions and this result is consistent across commercial orientation and ownership form. Other factors affecting the growth of microfinance institutions include age (new microfinance institutions grow faster than young and mature counterparts), levels of bad debt, efficiency and regulation.
\end{abstract}

Keywords: Gibrat's law; growth; microfinance; outreach; persistence

JEL Classification: G21; G32; L25 


\section{Introduction}

This paper examines the growth of microfinance institutions. Over the past 20 years or so microfinance institutions have enabled millions of poor people to access financial services resulting in increases in living standards and reduced poverty (Ledgerwood, Earne, \& Nelson, 2013). Microfinance institutions have also provided funding for entrepreneurial activity, which has led to subsequent gains in investment, employment and wealth creation (Morduch, 1999). As such, an understanding of the factors determining the growth of microfinance institutions is an important endeavour given their importance in promoting financial inclusion and providing funding for entrepreneurship.

Microfinance institutions vary in terms of ownership form, comprising micro-banks, nongovernmental organizations (NGOs), cooperatives/credit unions and non-bank financial institutions (NBFIs). Differences across ownership forms are likely to lead to differences in the strategies and objectives pursued by microfinance institutions.

Microfinance institutions also vary by commercial orientation. Some microfinance institutions act as not-for-profit organizations and focus on providing credit to the very poor at relatively generous repayment terms. These institutions seek to cover operating costs. Their social mission is one of financial inclusion and poverty reduction. In contrast, other microfinance institutions are organised as commercial for-profit financial institutions offering traditional financial products to clients across the entire income distribution. These microfinance institutions still seek to provide access to finance to poorer communities, but do not necessarily offer the level of access to the very poorest segments of society. This has led to some commentators questioning whether these for-profit microfinance institutions have deviated from their traditional purpose and experienced the so-called mission drift by striving to serve better off customers (Cull, Demirgüç-Kunt, \& Morduch, 2009; Ledgerwood et al., 2013; Mersland \& Strøm, 2010). 
In spite of the importance of microfinance institutions in providing access to finance, there is only a limited amount of research on the growth of microfinance institutions. This paper attempts to fill this gap by exploring the growth of microfinance institutions across a large number of countries and complementing the literature that has examined drivers and impact of outreach (Cull et al., 2009; Cull \& Morduch, 2007; Hermes \& Lensink, 2007; Hermes, Lensink, \& Meesters, 2011; Imai, Gaiha, Thapa, \& Annim, 2012).

Prior empirical literature investigating the determinants of firm growth tests Gibrat's Law, which posits that chance or random factors are central in determining the growth of individual firms, and in generating any resultant size distribution (Gibrat, 1931). Gibrat's Law comprises a set of testable hypotheses as follows: $(i)$ a firm's growth rate is not related of its size; (ii) a firm's growth rate is not persistent; and (iii) a firm's growth variability is independent of its size. If these hypotheses are upheld, a firm's growth rate is not deterministic (i.e. follows a random walk pattern) and therefore it is independent of any other observable characteristics such as firm size or prior growth.

Empirical evidence related to Gibrat's Law is extensive for manufacturing and financial services industries and provides rather mixed results. Some studies provide supporting evidence for Gibrat's Law, while others finding a systematic relationship between firm size and growth. ${ }^{1}$

In this paper, we investigate the relationship between the size and growth of microfinance institutions. Specifically, we investigate the following questions: (i) Is there empirical evidence of a size-growth relationship for microfinance institutions? (ii) Does microfinance institution growth persist over time? (iii) Does the variability of growth vary

\footnotetext{
${ }^{1}$ Early studies testing Gibrat's Law include Hart and Prais (1956) and Simon and Bonini (1958). Useful reviews of this literature for non-financial firms can be found in Audretsch, Klomp, Santarelli, and Thurik (2004), Coad (2009), Lipczynski, Goddard, and Wilson (2017) and Sutton (1997).
} 
across the size distribution of microfinance institutions? (iv) What other factors drive microfinance institution growth?

In order to answer these questions, we construct an extensive data set comprising microfinance institutions located in 120 countries over the period 2000 to 2014. Our measures of size (total assets and number of active microfinance borrowers) are used as an input to compute the growth measures used as dependent variables in our empirical analysis. This allows us to both complement and augment prior literature that has examined the determinants of the level (rather than the growth) of microfinance institution outreach.

We investigate the impact of microfinance institution size on growth, and augment this with a set control variables (in addition to size) used in prior studies of financial institution growth (Goddard, McKillop, \& Wilson, 2002; Shehzad, De Haan, \& Scholtens, 2013). These include age, profitability (ROA), efficiency (cost-income ratio), solvency (capital-to-total assets ratio), bad debt and an indicator variable capturing whether microfinance institutions in a given country are subject to prudential regulation and supervision.

Managerial incentives are likely vary by the ownership form and commercial orientation of microfinance institutions (Galema, Lensink, \& Mersland, 2012). Therefore, we also present the results of our estimable model by ownership form and commercial orientation.

Due to the presence of a lagged dependent variable and time-series dimension in the study of the growth of microfinance institutions, we use the system GMM estimation for dynamic panel data (see Blundell and Bond (1998)). We conduct both a univariate and multivariate analyses of the size-growth relationship to account for the effect of financial and non-financial factors on the growth rate of microfinance institutions. To examine whether growth rates differ across ownership form and by commercial orientation, the estimations are 
repeated for micro-banks, cooperatives/credit unions, NBFIs and NGOs, and for profit and not-for-profit microfinance institutions. This approach allows us to identify whether differences in operational structure and objective function affect the growth rates of microfinance institutions.

Our findings suggest that we cannot reject the hypotheses that microfinance institution growth is independent of size and cannot reject the hypothesis that there is no persistence in microfinance growth. However, we strongly reject the hypotheses that microfinance institution growth variability is independent of size. Our results remain consistent when disaggregated by commercial orientation and ownership form. The only exception is for non-profit microfinance institutions and credit unions/cooperative microfinance institutions where we find evidence of negative growth persistence (in total assets). Our results also suggest that other factors such as age (new microfinance institutions grow faster than young and mature counterparts), level of bad debt (which is associated to lower growth rates), efficiency, and regulation exert an important influence on the growth of microfinance institutions.

Our study makes four contributions to the literature. First, by focusing on microfinance institutions, we contribute to a literature (reviewed in Section 2) that has tested Gibrat's Law for the mainstream financial services industry. Second, we extend previous empirical research that examines the determinants of the level of microfinance institution outreach (Cull, Demirgüç-Kunt, \& Morduch, 2011; Hartarska, Shen, \& Mersland, 2013; Hermes et al., 2011). Third, we present evidence on the drivers of growth for microfinance institutions with different ownership forms and commercial orientation. As such we contribute to an established literature which suggests that ownership form contributes to differences in financial performance across shareholder based and mutually owned organizations (Ferri, Kalmi, \& Kerola, 2014; Iannotta, Nocera, \& Sironi, 2007). Fourth, to 
account for the dynamic effects between size and growth along with any endogeneity issues, we employ system GMM estimation for dynamic panel models. Overall, the results of this study provide a detailed picture of the growth patterns for a worldwide sample of microfinance institutions for the period 2000 to $2014 .^{2}$

The rest of this paper is organized as follows. Section 2 provides a background to the current study and a review of prior literature. Section 3 presents the data and methodology. In Section 4, we discuss the results of the empirical analysis. Section 5 provides concluding comments.

\section{Background and Literature}

\section{Background}

The lack of access to affordable financial services is one of the underlying reasons for the levels of poverty observed in many developing countries. Microfinance institutions offer financial services, for the most part loans, to individuals and groups of people in order to meet their short-term consumption and investment needs. Microfinance institutions provide access to finance to those individuals (lacking credit histories and collateral) who are normally excluded from mainstream financial services (Cull et al., 2009; Hermes et al., 2011; Ledgerwood et al., 2013; Morduch, 1999). ${ }^{3}$

Microfinance institutions have adopted different ownership forms worldwide. These include Micro-banks, Non-bank financial institutions (NBFIs), cooperatives/credit unions and NGOs. Micro-banks and NBFIs are shareholder-oriented organizations targeting traditional financial performance metrics (Galema et al., 2012; Mersland, 2009). Micro-banks have flexible capital structures (funded by both socially and financially motivated investors) and

\footnotetext{
${ }^{2}$ Countries covered in our sample are reported in Table A1 in the Appendix.

${ }^{3}$ Recent estimates suggest that the microfinance sector reached 211 million clients at the end of 2013, and approximately 54\% of those clients were living in extreme poverty (Reed et al., 2015).
} 
are commercially oriented institutions. NFBIs are similar to Micro-banks, and account for all other types of microfinance institutions with limitations on the range of financial products that they can offer (e.g. ability to take deposits and sell insurance products).

Cooperatives/credit unions are not-for-profit organizations. Members are the owners of these institutions and exert control over strategic decisions. Surpluses are retained to build up capital or distribute to members directly via cash dividends or indirectly via low cost access to credit and deposit services. Access to external funding is limited and owners are involved in the management of the microfinance institution. NGOs are also not-for-profit organizations, but in contrast to credit unions are characterized by a non-distribution constraint (Servin, Lensink, \& Van Den Berg, 2012). ${ }^{4}$ The range of financial services provided by NGOs is rather limited given that these institutions cannot accept deposits. The dependence on external funding such as grants and subsidies (rather than shareholder capital) make them less responsive to changes in demand and supply conditions. NGOs are commonly associated with lower profitability, smaller loan sizes and higher costs per dollar lent compared to commercially oriented micro-banks (Cull et al., 2009).

The mission of most microfinance institutions is based on the so-called "double bottomline" approach: to achieve simultaneously financial self-sufficiency and social objectives (Hermes et al., 2011). However, financial objectives tend to be more important for Microbanks/NBFIs relative to their Credit Unions/NGOs counterparts. Microfinance institutions are also classified in terms of their commercial orientation as for-profit (shareholder-based organizations) and not-for-profit microfinance institutions. Commercial micro-banks usually share a for-profit orientation; however, NGOs are more likely to have a non-profit status (Cull et al., 2009). Périlleux, Hudon, and Bloy (2012) find that ownership structure of

\footnotetext{
${ }^{4}$ Galema et al. (2012) argue that managerial discretion is more prevalent in non-governmental organizations than in other types of microfinance institutions.
} 
microfinance institutions matters in the allocation of surplus to stakeholders. The authors suggest that non-profit organizations and shareholders-held microfinance institutions tend to keep their surplus, while cooperatives/credit unions show a preference to distribute surpluses to providers and employees.

\section{Literature}

Gibrat (1931) was the first to develop the view that a firm's growth in each period follows a random pattern. A relatively large body of literature has tested the validity of the Gibrat's Law based on three testable hypotheses: (H1) firm growth is not related to size; $(\mathrm{H} 2)$ firm growth is not persistent; and $(H 3)$ the variability in firm growth is not related to firm size. Thus failing to reject these three hypotheses provides empirical support to Gibrat's Law that firm growth occurs mostly due to chance.

Gibrat's Law has been widely tested in manufacturing and services industries, and to a lesser extent for mainstream financial intermediaries operating in advanced economies. ${ }^{5}$ Early studies using data from 1930s through to the early 1970s investigate patterns of growth for US banks and find an inverse size-growth relationship (Alhadeff \& Alhadeff, 1964; Rhoades \& Yeats, 1974). Tschoegl (1983) tests empirically the relationship between size and growth using the 100 largest banks worldwide in the 1970s. His results suggest that: growth is unrelated to bank size; growth is not persistent; and large banks tend to have less variable growth rates than smaller banks.

Wilson and Williams (2000) find no significant relationship between size (proxied by total assets, total equity and value of off balance sheet activities) and growth for European banks during the period 1990-1996. The authors do find however a negative size-growth relationship for Italian banks. Furthermore, their results suggest that large banks tend to

\footnotetext{
${ }^{5}$ Coad (2009), Lipczynski et al. (2017) and Sutton (1997) provide useful reviews of this literature.
} 
exhibit less variable growth rates compared to small banks. Goddard et al. (2002) investigate the determinants of the growth of US credit unions between 1990 and 1999. The authors find evidence of a positive size-growth relationship, persistence in growth rates is negative, and a negative relationship between variability in growth rates and size. Goddard, Molyneux, and Wilson (2004) examine the growth of the largest banks operating in France, Germany, Italy, Spain, and the UK in the 1990s. The authors find that growth rates for larger banks is on average higher compared to smaller counterparts. The authors also provide some evidence suggesting that banks exhibit positive persistence in growth. Ward and McKillop (2005) test Gibrat's Law for a sample of credit unions in the UK over the period 1994 to 2000. The authors find that: smaller credit unions grew faster than larger counterparts; growth is persistent over time; and smaller credit unions have more variable growth than larger counterparts. A recent study by Shehzad et al. (2013), exploring growth determinants for a sample of 148 banking firms operating in OECD and developing countries finds that Gibrat's Law holds for the banking industry over the period 1988-2010.

\section{Data and Methods}

\section{Data}

We collect financial and non-financial data for microfinance institutions worldwide from the MIX Market database. This database has been used widely in prior microfinance research (Barry \& Tacneng, 2014; Bogan, 2012; Postelnicu \& Hermes, 2016). Microfinance institutions report financial data to MIX on a voluntary basis. To ensure the quality of data, the MIX database uses a diamond rating scheme to indicate the level of disclosure by MFIs. 
The ratings go from one to five diamonds, with five diamonds indicating that an MFI adheres to the highest disclosure standards. ${ }^{6}$

Following previous literature, we limit our sample to microfinance institutions that are assigned three or more diamonds (Assefa, Hermes, \& Meesters, 2013; Barry \& Tacneng, 2014). Our data span the period 2000 through 2014 and includes microfinance institutions of different ownership form (micro-banks, NBFI, cooperatives/credit unions and NGOs). Our sample includes a heterogeneous set of microfinance institutions in terms of relevant characteristics such as size, growth, profitability, ownership form and operating in different geographical areas. ${ }^{7}$ We winsorize all variables at the $1 \%$ of the distribution (top and bottom) to remove outliers in the data set. ${ }^{8}$ After these changes, our final sample includes almost 13,000 observations. Due to the unbalanced nature of our data and missing values for some variables, the number of usable observations varies across the models estimated in Section 4.

We employ two size measures in our empirical analysis: total assets and total number of active borrowers. In line with previous studies, we rely on total assets as our primary size measure. One of the most important characteristics of microfinance institutions is the provision of financial services and products to the poor and therefore the expansion of the assets can be considered as one of its main strategic objectives. As an alternative size measure, we also use the total number of active microfinance borrowers. Achieving higher growth rates in the number of active borrowers represents a key outreach target for most of

\footnotetext{
${ }^{6}$ One diamond is granted to microfinance institutions with a visible profile at MIX Market. Two diamonds implies one diamond along with some data on products and clients for the year. Three diamonds implies two diamonds plus reported financial data for the year. Four diamonds implies the same availability of data as with three diamonds plus audited financial statements for the year. Five diamonds represent data as with four diamonds plus ratings and other due diligence report for the year. Definitions of diamond ratings are available in MIX market (https://www.themix.org/resource/what-are-diamonds-rankings).

${ }^{7}$ The analysis of entry and exit decisions of market participants is beyond the scope of the paper. Nevertheless, this dataset reflects the market structure and different levels of voluntary reporting of microfinance institutions operating in different countries.

${ }^{8}$ Winsorizing all variables at the $5^{\text {th }}$ and $95^{\text {th }}$ or $10^{\text {th }}$ and $90^{\text {th }}$ percentiles do not change our main findings, suggesting that our results are not driven by outliers.
} 
the microfinance institutions. By comparing the results based on these measures, we are able to analyse the relationships between size and growth process from two different perspectives which are particularly relevant for microfinance institutions. In this regard, it could be argued that microfinance institutions pursuing higher levels of outreach are expected to achieve specific levels of growth by including certain objectives in terms of total assets and number of active borrowers.

Table 1a presents the summary statistics (mean, standard deviation, percentiles, minimum/maximum values and number of observations) of the variables included in the regression. The mean values displayed in the Table indicate that an average MFI in our sample has a ROE, OER, CAR and PaR30 of $0.58 \%, 28.5 \%, 35.87 \%$ and $6.51 \%$ respectively.

\section{<Insert Table 1a about here>}

Table $1 \mathrm{~b}$ presents descriptive statistics by ownership form and commercial orientation. On average micro-banks and NBFIs are larger than credit unions and NGOs. Credit Unions and NBFI, however, are similar in terms of ROA. Micro-banks enjoy higher levels of financial performance. Efficiency, capital and bad debt ratios are similar across different ownership forms. All ownership forms experience positive average growth in assets. For-profit microfinance institutions stand out with an average growth in assets and active borrowers during the period of $3.08 \%$ and $3.54 \%$ respectively.

\section{$<$ Insert Table 1b about here>}

\section{Estimable model}


Our econometric model describes the relationship between microfinance institution size and growth as follows:

$g_{i t}=\alpha_{i}+\theta S_{i t-1}+\delta_{t}+\vartheta_{j}+\varepsilon_{i t}(1)$

Where $g_{i t}=\log \left(S_{i t}\right)-\log \left(S_{i t-1}\right)$ is the (logarithmic) growth of microfinance institution $i$ between years $t-1$ and $t . S_{i t-1}$ indicates the (logarithmic) size of microfinance institution $i$ (in terms of total assets or number of active borrowers) in year $t-1$, and $\alpha_{i}, \delta_{t}, \vartheta_{j}$ are individual, time and regional fixed effects, respectively. ${ }^{9} \theta$ captures any size-growth relationship for microfinance institutions. To study the influence of past growth on current growth, we introduce a lagged dependent variable along with a set of additional control variables as follows:

$g_{i t}=\alpha_{i}+\theta\left(S_{i t-1}\right)+\rho\left(g_{i t-1}\right)+\tau X_{i t-1}+\delta_{t}+\vartheta_{j}+\varepsilon_{i t}$

If microfinance institution specific effects are heterogeneous $\left(\alpha_{i} \neq \alpha\right), \theta$ becomes an inconsistent and biased estimator. Following Goddard et al. (2002), Goddard et al. (2004) and Shehzad et al. (2013) we address this issue by taking the difference of lagged size and initial microfinance size in Equation (2) and adding the individual fixed effects $\left(\alpha_{i}\right)$ to the error component $\left(\epsilon_{i t}\right)$ as follows:

$$
g_{i t}=\theta\left(S_{i t-1}^{\prime}\right)+\rho\left(g_{i t-1}\right)+\tau X_{i t-1}+\delta_{t}+\vartheta_{j}+\epsilon_{i t}(3)
$$

\footnotetext{
${ }^{9}$ The regions are Latin America and The Caribbean, Africa, Eastern Europe and Central Asia, East Asia and the Pacific, Middle East and North Africa, and South Asia.
} 
Where $S_{i t-1}^{\prime}=S_{i t-1}-S_{i 0}$ and $\epsilon_{i t}=\varepsilon_{i t}+\alpha_{i}+\theta S_{i 0}$. This provides an unbiased and consistent estimation of the model. Similar to Goddard et al. (2004), $g_{i t}$ is normalized by removing from each observation the cross-sectional average in each year. Although microfinance institutions share a common social mandate, there are still substantial differences in terms of their operational and financial characteristics. To account for these differences we include a set of time-varying control variables $\left(X_{i t}\right)$. First, we include a categorical variable that captures the stage of the microfinance institution in its life cycle (new, young and mature) which is expected to influence its growth patterns. For example, microfinance institutions that are mature and perhaps less innovative than their younger counterparts could face challenges in sustaining higher growth rates. Second, we include the Return on Assets (ROA) as internally retained funds are likely to exert a positive effect on the growth rate of microfinance institutions. Third, we control by the level of operational efficiency of the microfinance institution. A low operational efficiency (high cost-income ratio) is likely to be associated with inefficient performance, and could have a negative effect on growth. Fourth, the capital-to-assets ratio is included to account for differences in levels of solvency between microfinance institutions. The expected relationship between capital and growth rate could be either positive or negative. Microfinance institutions with higher capital ratios are likely to be perceived as less risky, and thus able to attract funding and follow a sustainable growth trajectory. Equally, if microfinance institutions hold capital well above the optimum level, then profitable opportunities may be foregone and thus finance for future growth inhibited. Fifth, we include the portfolio at risk over 30 days as a percentage of the total loan portfolio (PaR30). The relationship between bad debt and growth is expected to be negative as it could reflect poor risk management strategies of the microfinance institution, which in turn can damage its future growth prospects. Finally, we include lagged GDP 
growth in country $k$ (where microfinance $i$ operates) and year $t$ to control for macroeconomic factors affecting the microfinance sector.

Equation (3) allows us to test empirically Gibrat's Law's three hypothesis: (H1) whether microfinance institution growth is unrelated to size, which consists of testing $H_{0}: \theta=0$, with the alternative that $H_{0}: \theta \neq 0 . \theta=0$ implies that there is no relationship between size and growth. $\theta \neq 0$ implies a positive or negative size-growth relationship. (H2) the hypothesis that growth rates are not persistence is tested by the null hypothesis $H_{0}: \rho=0$ under the alternative that $H_{0}: \rho \neq 0$. The sign of $\hat{\rho}$ indicates if persistence is either positive or negative. Finally, following Goddard et al. (2002), we test whether growth variability is independent of microfinance size (H3) by using a Lagrange multiplier (LM) test, under the null hypothesis of homoscedasticity of error terms. The test relies on an auxiliary regression where the squared residuals obtained from estimating equation (3) are regressed on the squared lagged size variable. A rejection of the null implies that growth variability depend on the microfinance size. The sign of the estimated squared lagged size variable reflects the direction of the size-variability of growth relationship. Thus, failing to reject $\mathrm{H} 1, \mathrm{H} 2$ and $\mathrm{H} 3$ implies that the growth patterns of firms follow a random walk, verifying the Gibrat's Law.

Due to the presence of the lagged dependent variable in Equation (3), we use the twostep system GMM estimator (Blundell \& Bond, 1998) with corrected standard errors (Windmeijer, 2005) to estimate equation (3). The consistency of the system GMM estimator depends on two conditions: (i) the validity of the instruments and (ii) the absence of secondorder serial correlation $(\mathrm{AR}(2))$ in the differenced residuals. The first condition is tested by using the Hansen test of over identifying restrictions under the null that the instruments are uncorrelated with the error term. To avoid the problems caused by instrument proliferation, the number of instruments is reported in all Tables and is always lower than the number of cross-sectional units (Roodman, 2009a, 2009b). The second condition is tested by using the 
serial correlation Arellano-Bond (AB) test (Arellano \& Bond, 1991). An insignificant AB test for $\operatorname{AR}(2)$ autocorrelation indicates that the model is correctly specified. Results of both tests are reported at the bottom of the Tables. We also report in all Tables a multicollinearity test (i.e. variance inflation factor (VIF)) using a linear regression model (OLS). ${ }^{10}$ Finally, we estimate the models using robust standard errors clustered at country level to account for correlation of errors within countries.

\section{Results}

Tables 2 and 3 summarise the results of estimating the univariate (model 1) and multivariate (model 2) growth models. Total assets and number of active borrowers are used as size measures. The first row reports the estimated coefficients, which identify the sizegrowth relationship. The second row includes estimated coefficients that reflect growth persistence from one period to the next. All tables report the heteroscedasticity LM test (LM test) along with the estimated lagged squared size coefficient (Hetero). The sign of the coefficient describes the direction of the relationship between size and variability of growth rates. Estimates for the full sample and by ownership forms are also reported in each table.

To test our first hypotheses that microfinance institution growth is independent of size, we examine the coefficient of lagged logarithmic microfinance institution size. Results for univariate and multivariate models show that the coefficient on size is insignificant both in our full sample and for each of the four ownership forms. The lack of significance of any size-growth relationship suggests that there are no significant advantages accruing to larger microfinance institutions (e.g. in terms of scale economies) either in terms of higher levels of lending or the number of active microfinance borrowers.

\footnotetext{
${ }^{10}$ Table A2 in the Appendix reports the correlation matrix of the full set of variables employed in the empirical analysis. The correlation between covariates used in our empirical models is low.
} 
We also test the hypothesis of non-persistence of growth for microfinance institution. Although the analysis of the full sample for total assets (Table 2) does not show signs of persistence, we find some evidence of negative persistence (mean-reversion) in certain types of ownership form. In particular, the results imply that high levels of growth in assets of cooperatives/credit unions leads to below-average growth in assets the next period. In the case of number of active borrowers as a size measure (Table 3), our univariate regressions show evidence of positive persistence of growth for the full sample only. However, this coefficient is insignificant in our preferred multivariate model and across the different ownership forms. Overall, our findings imply that prior microfinance institution growth (in terms of number of active borrowers) has no predictive power for current microfinance growth.

To examine the effect of microfinance institution size on variability of growth, we consider the heteroscedasticity test reported in Tables 2 and 3. We reject the null hypothesis of homoscedastic growth across all models, which points out the presence of heteroscedasticity and describe a negative relationship between size and growth variability. Previous empirical studies have reported similar results for other industries (Goddard et al., 2002). This result suggests that small (less diversified) microfinance institutions may be more vulnerable to economic fluctuations and therefore subject to greater variability in growth (Dunne \& Hughes, 1994).

\section{<Insert Tables 2 and 3 about here>}

Finally, we discuss the effect of the control variables on microfinance growth in the multivariate regression. For the growth models reported in Tables 2 and 3, our results indicate that age is a key determinant of growth, with new microfinance institutions growing faster than young and mature counterparts. Our results also suggest that an increase in the cost-to- 
income ratio (efficiency) increases the growth of cooperatives/credit unions. Our results suggest that bad debt tends to reduce growth of MFIs, but particularly in the case of NGOs. Finally, we find that regulation of microfinance institutions exerts a positive effect on asset growth and growth in the number of active borrowers in the case of NGOs.

As a robustness check, we re-estimate the models by considering the commercial orientation of microfinance institutions. In general terms, profit-oriented microfinance institutions include shareholder oriented institutions such as Micro-banks and NBFIs, while not-for-profit oriented microfinance institutions are mainly constituted as cooperatives/credit unions and NGOs.

Table 4 presents the results for our estimated models for both groups and two measures of size. Wald Chi-squared tests suggest that all variables are jointly significant at the $1 \%$ level and should not be dropped from the models. The Hansen test as well as the AR(2) test always appear insignificant, implying that the models are correctly specified. Similar to previous results, we find that microfinance institution growth is independent of microfinance size. We also find evidence of a negative persistence of growth in assets for not-for-profit microfinance institutions, which suggests that past growth rates have predictive power for current growth rates. Finally, and in common with the results of the rest of our results discussed above, microfinance institution growth variability is related to size. Table 5 presents a summary of the main results of the estimated models.

\section{<Insert Tables 4 and 5 about here>}

We also carry out a battery of robustness checks. First, we restrict our sample to those microfinance institutions with at least nine years of available data (which correspond to the median value of the sample distribution). Second, we restrict the sample to countries with at 
least 36 microfinance institutions (which corresponds to the median value of the distribution in our sample). Third, we limit our analysis to countries with at least 36 microfinance institutions and at least nine years of available data. Results using different types of consistent panel remain unchanged, suggesting that our key findings are not driven by entry and exit of microfinance institutions in the sample. Results are reported in Tables A3 and A4 in the Appendix. Finally, we consider the case that disclosure of information is endogenous. It could be because the disclosure of information to the MIX database is on a voluntary basis with a rating scheme (i.e. diamonds) indicating the level of disclosure. This might generate self-selection bias in that those microfinance institutions providing more disclosure are the more developed and that experienced higher growth in the past. We conduct a robustness check to test whether self-selection or endogeneity of disclosure could be affecting our results. To this end, we estimate regressions including the lagged level of disclosure as control variable and treat it as endogenous within our GMM dynamic panel framework. The results are reported in Table A5 in the Appendix and are similar to those presented in Tables $2-3 .^{11}$

\section{Conclusion}

Microfinance institutions play an important role in many countries as providers of financial services to the poor. Employing dynamic panel data methods we assess the growth

\footnotetext{
${ }^{11}$ We also explore the possibility that synergies between commercial orientation and ownership model could affect our key findings. In particular, we include a full set of interaction terms to take into account simultaneously the operational structure (i.e. ownership models) and the objective functions (i.e. commercial orientation) of MFIs. Our main findings remain unchanged. In order to conserve space, we do not report the results of these additional regressions. These results are available from the authors upon request. We thank a referee for suggesting this additional test.
} 
of microfinance institutions worldwide during the period 2000-2014. Our analysis allows us to test three hypotheses that, if accepted, imply that the size distribution of microfinance institutions is the outcome of a sequence of random shocks. We use two alternative measures of size: total assets (which is related to the objective of increasing the provision of loans) and number of active microfinance borrowers (which is associated with social outreach targets). Our findings suggest that: microfinance institution growth is independent of size; microfinance institution growth is not persistent; and that the variability in microfinance institution growth decreases with size. These results are robust with respect to ownership form and commercial orientation.

Overall, these results imply that Gibrat's Law does not hold for microfinance institutions. Additionally, our results identify systematic factors which influence microfinance institution growth. Specifically, microfinance institutions that are: new; more efficient; with lower levels of bad debt; and regulated record higher growth levels, after controlling for other determinants of growth. Overall, the results of this study are of interest to academics, policymakers and regulators in better understanding the dynamics of asset growth and borrower outreach in the microfinance industry.

\section{References}

Alhadeff, D., \& Alhadeff, C. (1964). Growth of Large Banks, 1930-1960. Review of Economics and Statistics, 46, 356-363.

Arellano, M., \& Bond, S. (1991). Some Tests of Specification for Panel Data: Monte Carlo Evidence and an Application to Employment Equations. Review of Economic Studies, $58,277-297$.

Assefa, E., Hermes, N., \& Meesters, A. (2013). Competition and the Performance of Microfinance Institutions. Applied Financial Economics, 23, 767-782. 
Audretsch, D. B., Klomp, L., Santarelli, E., \& Thurik, A. R. (2004). Gibrat's Law: Are the Services Different? Review of Industrial Organization, 24, 301-324.

Barry, T. A., \& Tacneng, R. (2014). The Impact of Governance and Institutional Quality on MFI Outreach and Financial Performance in Sub-Saharan Africa. World Development, 58, 1-20.

Blundell, R., \& Bond, S. (1998). Initial Conditions and Moment Restrictions in Dynamic Panel Data Models. Journal of Econometrics, 87, 115-143.

Bogan, V. L. (2012). Capital Structure and Sustainability: An Empirical Study of Microfinance Institutions. Review of Economics and Statistics, 94, 1045-1058.

Coad, A. (2009). The Growth of Firms: A Survey of Theories and Empirical Evidence: Edward Elgar Publishing.

Cull, R., Demirgüç-Kunt, A., \& Morduch, J. (2009). Microfinance Meets the Market. Journal of Economic Perspectives, 23, 167-192.

Cull, R., Demirgüç-Kunt, A., \& Morduch, J. (2011). Does Regulatory Supervision Curtail Microfinance Profitability and Outreach? World Development, 39, 949-965.

Cull, R., \& Morduch, J. (2007). Financial Performance and Outreach: A Global Analysis of Leading Microbanks. The Economic Journal, 117, F107-F133.

Dunne, P., \& Hughes, A. (1994). Age, Size, Growth and Survival: UK Companies in the 1980s. Journal of Industrial Economics, 42, 115-140.

Ferri, G., Kalmi, P., \& Kerola, E. (2014). Does Bank Ownership Affect Lending Behavior? Evidence from the Euro Area. Journal of Banking \& Finance, 48, 194-209.

Galema, R., Lensink, R., \& Mersland, R. (2012). Do Powerful Ceos Determine Microfinance Performance? Journal of Management Studies, 49, 718-742.

Gibrat, R. (1931). Les Inégalités Économiques: Recueil Sirey. 
Goddard, J. A., McKillop, D. G., \& Wilson, J. O. S. (2002). The Growth of US Credit Unions. Journal of Banking \& Finance, 26, 2327-2356.

Goddard, J. A., Molyneux, P., \& Wilson, J. O. (2004). Dynamics of Growth and Profitability in Banking. Journal of Money, Credit and Banking, 36, 1069-1090.

Hart, P. E., \& Prais, S. J. (1956). The Analysis of Business Concentration: A Statistical Approach. Journal of the Royal Statistical Society. Series A (General), 119, 150-191. Hartarska, V., Shen, X., \& Mersland, R. (2013). Scale Economies and Input Price Elasticities in Microfinance Institutions. Journal of Banking \& Finance, 37, 118-131.

Hermes, N., \& Lensink, R. (2007). The Empirics of Microfinance: What Do We Know? The Economic Journal, 117, F1-F10.

Hermes, N., Lensink, R., \& Meesters, A. (2011). Outreach and Efficiency of Microfinance Institutions. World Development, 39, 938-948.

Iannotta, G., Nocera, G., \& Sironi, A. (2007). Ownership Structure, Risk and Performance in the European Banking Industry. Journal of Banking \& Finance, 31, 2127-2149.

Imai, K. S., Gaiha, R., Thapa, G., \& Annim, S. K. (2012). Microfinance and Poverty—a Macro Perspective. World Development, 40, 1675-1689.

Ledgerwood, J., Earne, J., \& Nelson, C. (2013). The New Microfinance Handbook: A Financial Market System Perspective: World Bank Publications.

Lipczynski, J., Goddard, J., \& Wilson, J. O. S. (2017). Industrial Organization: Competition, Strategy and Policy (5 $5^{\text {th }}$ ed.). Harlow, England: Pearson.

Mersland, R. (2009). The Cost of Ownership in Microfinance Organizations. World Development, 37, 469-478.

Mersland, R., \& Strøm, R. Ø. (2010). Microfinance Mission Drift? World Development, 38, 28-36. 
Morduch, J. (1999). The Microfinance Promise. Journal of Economic Literature, 37, 15691614.

Périlleux, A., Hudon, M., \& Bloy, E. (2012). Surplus Distribution in Microfinance: Differences among Cooperative, Nonprofit, and Shareholder Forms of Ownership. Nonprofit and Voluntary Sector Quarterly, 41, 386-404.

Postelnicu, L., \& Hermes, N. (2016). Microfinance Performance and Social Capital: A CrossCountry Analysis. Journal of Business Ethics, 1-19.

Reed, L. R., Diaz, F., Gailly, S., Marsden, J., Rivera, C., Rogers, S., \& Sanchez, X. (2015). Mapping Pathways out of Poverty: The State of the Microcredit Summit Campaign Report 2015: Microcredit Summit Campaign.

Rhoades, S. A., \& Yeats, A. J. (1974). Growth, Consolidation and Mergers in Banking. Journal of Finance, 29, 1397-1405.

Roodman, D. (2009a). How to Do Xtabond2: An Introduction to Difference and System GMM in Stata. Stata Journal, 9, 86.

Roodman, D. (2009b). A Note on the Theme of Too Many Instruments. Oxford Bulletin of Economics and Statistics, 71, 135-158.

Servin, R., Lensink, R., \& Van Den Berg, M. (2012). Ownership and Technical Efficiency of Microfinance Institutions: Empirical Evidence from Latin America. Journal of Banking \& Finance, 36, 2136-2144.

Shehzad, C. T., De Haan, J., \& Scholtens, B. (2013). The Relationship between Size, Growth and Profitability of Commercial Banks. Applied Economics, 45, 1751-1765.

Simon, H. A., \& Bonini, C. P. (1958). The Size Distribution of Business Firms. American Economic Review, 48, 607-617.

Sutton, J. (1997). Gibrat's Legacy. Journal of Economic Literature, 35, 40-59. 
Tschoegl, A. E. (1983). Size, Growth, and Transnationality among the World's Largest Banks. Journal of Business, 56, 187-201.

Ward, A. M., \& McKillop, D. G. (2005). The Law of Proportionate Effect: The Growth of the UK Credit Union Movement at National and Regional Level. Journal of Business Finance \& Accounting, 32, 1827-1859.

Wilson, J. O., \& Williams, J. (2000). The Size and Growth of Banks: Evidence from Four European Countries. Applied Economics, 32, 1101-1109.

Windmeijer, F. (2005). A Finite Sample Correction for the Variance of Linear Efficient TwoStep GMM Estimators. Journal of Econometrics, 126, 25-51. 
Table 1a. Summary statistics

\begin{tabular}{lcccccccc} 
& Mean & SD & p5 & p50 & p95 & Min & Max & N \\
\hline \hline Total assets (US\$ 000) & 38,600 & 116,000 & 139 & 4,028 & 195,000 & 21 & 834,000 & 12,801 \\
Growth in assets (\%) & 1.85 & 3.44 & -1.34 & 1.38 & 6.52 & -50.82 & 52.70 & 10,039 \\
Number of active borrowers & 41,916 & 123,128 & 165 & 6,685 & 180,885 & 30 & 932,286 & 12,828 \\
Growth in borrowers (\%) & 2.53 & 6.94 & -3.95 & 1.49 & 12.09 & -64.92 & 99.32 & 10,069 \\
Age & 2.42 & 0.78 & 1.00 & 3.00 & 3.00 & 1 & 3 & 13,032 \\
ROA (\%) & 0.58 & 10.72 & -18.40 & 1.91 & 12.90 & -55.34 & 23.05 & 10,368 \\
OER (\%) & 28.50 & 26.71 & 6.12 & 19.65 & 80.38 & 2.54 & 163.82 & 10,373 \\
CAR (\%) & 35.87 & 28.07 & 2.55 & 27.86 & 93.81 & -22.43 & 100.00 & 12,717 \\
PaR30 (\%) & 6.51 & 9.65 & 0.00 & 3.56 & 23.97 & 0.00 & 59.62 & 10,712 \\
GDP growth (\%) & 5.30 & 3.20 & 0.09 & 5.25 & 10.26 & -4.70 & 14.04 \\
\hline \hline
\end{tabular}

Notes: Table 1a reports for each variable in our sample the mean, standard deviations (SD), the fifth (p5), fiftieth (p50), ninety-fifth percentile (p50), minimum, maximum values and number of observations for the period $2000-2014$. Active borrowers are those who have an outstanding loan balance or are responsible for repaying a loan. Age is a categorical variable (1: New (1 to 4 years); 2: Young (5 to 8 years): and 3: Mature (More than 8 years)). Return on Assets (ROA): Net income/total assets, efficiency ratio (OER): Operating costs/average gross portfolio. OER measures the costs necessary for an institution to provide credit. The lower the ratio, the more efficient the institution is. Ratio of solvency (CAR): Total equity/total assets. PaR30 is defined as the proportion of a loan portfolio that is more than 30 days in arrears and it is measured as follows: (Outstanding balance on arrears over 30 days + total gross outstanding refinanced (restructured) portfolio)/total gross portfolio. It shows the part of the portfolio affected by outstanding payments, where there is a risk that they will not be repaid. GDP growth is from the World Development Indicators (WDIs) published by the World Bank. Please refer to MIX market for an exact definition of microfinance-related variables (https://www.themix.org/resource/glossary/glossary). 
Table 1b. Summary statistics by ownership type and commercial orientation

\begin{tabular}{|c|c|c|c|c|c|c|}
\hline & \multicolumn{4}{|c|}{ Ownership Type } & \multicolumn{2}{|c|}{ Commercial orientation } \\
\hline & Micro-bank & $\begin{array}{l}\text { Cooperatives/ } \\
\text { credit unions }\end{array}$ & NBFI & NGO & $\begin{array}{c}\text { Registered in a non- } \\
\text { profit status }\end{array}$ & $\begin{array}{c}\text { Registered as a } \\
\text { for-profit } \\
\text { institution } \\
\end{array}$ \\
\hline \multicolumn{7}{|c|}{ Means and standard deviations (in italics) } \\
\hline Total assets (US\$ 000) & 168,000 & 21,500 & 34,400 & 12,700 & 22,200 & 66,000 \\
\hline Growth in assets (\%) & 2.71 & 3.64 & 3.85 & 3.11 & 3.21 & 3.54 \\
\hline \multirow[t]{2}{*}{ Number of active borrowers } & 94,272 & 11,189 & 47,135 & 36,830 & 31,157 & 61,800 \\
\hline & 192,462 & 41,935 & 132,130 & 108,898 & 98,261 & 155,070 \\
\hline \multirow[t]{2}{*}{ Growth in borrowers (\%) } & 2.46 & 2.41 & 3.06 & 2.09 & 2.06 & 3.08 \\
\hline & 5.53 & 7.55 & 7.90 & 6.01 & 6.21 & 7.62 \\
\hline \multirow[t]{2}{*}{ Age } & 2.33 & 2.45 & 2.23 & 2.62 & 2.57 & 2.23 \\
\hline & 0.84 & 0.75 & 0.83 & 0.67 & 0.69 & 0.84 \\
\hline CAR $(\%)$ & 21.53 & 21.65 & 28.58 & 29.89 & 28.49 & 26.97 \\
\hline \multirow[t]{2}{*}{ PaR30 (\%) } & 6.12 & 7.92 & 6.02 & 6.42 & 6.63 & 6.21 \\
\hline & 9.84 & 10.00 & 9.19 & 9.77 & 9.55 & 9.58 \\
\hline
\end{tabular}

Notes: The Table reports summary statistics for the period 2000 - 2014. Table 1a above and MIX market provide detailed definitions of ownership forms (https://www.themix.org/resource/glossary/glossary). 
Table 2. Dynamic panel estimation results (Dependent variable: growth in assets)

\begin{tabular}{|c|c|c|c|c|c|c|c|c|c|c|}
\hline & \multicolumn{2}{|c|}{ All } & \multicolumn{2}{|c|}{ Micro-banks } & \multicolumn{2}{|c|}{ Cooperatives/credit unions } & \multicolumn{2}{|c|}{ NBFI } & \multicolumn{2}{|c|}{ NGO } \\
\hline & Model 1 & Model 2 & Model 1 & Model 2 & Model 1 & Model 2 & Model 1 & Model 2 & Model 1 & Model 2 \\
\hline$\theta: \log ($ Assets $(t-1))$ & $\begin{array}{l}0.015 \\
(0.85)\end{array}$ & $\begin{array}{l}0.020 \\
(1.43)\end{array}$ & $\begin{array}{l}0.005 \\
(0.18)\end{array}$ & $\begin{array}{l}0.007 \\
(0.30)\end{array}$ & $\begin{array}{l}-0.024 \\
(-0.95)\end{array}$ & $\begin{array}{l}-0.027 \\
(-0.90)\end{array}$ & $\begin{array}{l}0.007 \\
(0.24)\end{array}$ & $\begin{array}{l}0.020 \\
(0.74)\end{array}$ & $\begin{array}{l}0.035 \\
(1.27)\end{array}$ & $\begin{array}{l}0.016 \\
(0.57)\end{array}$ \\
\hline$\rho:$ Growth in assets $(t-1)$ & $\begin{array}{l}0.074 \\
(0.71)\end{array}$ & $\begin{array}{l}-0.051 \\
(-1.17)\end{array}$ & $\begin{array}{l}0.062 \\
(0.50)\end{array}$ & $\begin{array}{l}0.130 \\
(1.11)\end{array}$ & $\begin{array}{c}-0.133 * * * \\
(-5.72)\end{array}$ & $\begin{array}{c}-0.137 * * * \\
(-3.98)\end{array}$ & $\begin{array}{l}0.017 \\
(0.14)\end{array}$ & $\begin{array}{l}0.010 \\
(0.36)\end{array}$ & $\begin{array}{l}-0.030 \\
(-0.25)\end{array}$ & $\begin{array}{l}0.006 \\
(0.04)\end{array}$ \\
\hline Age: Young & & $\begin{array}{c}-1.020 * * * \\
(-5.89)\end{array}$ & & $\begin{array}{l}-0.230 \\
(-0.75)\end{array}$ & & $\begin{array}{l}-0.758 \\
(-1.59)\end{array}$ & & $\begin{array}{c}-0.930 * * * \\
(-4.10)\end{array}$ & & $\begin{array}{c}-1.347 * * \\
(-2.68)\end{array}$ \\
\hline Age: Mature & & $\begin{array}{c}-1.271 * * * \\
(-6.60)\end{array}$ & & $\begin{array}{l}-0.383 \\
(-1.22)\end{array}$ & & $\begin{array}{c}-1.250^{* *} \\
(-2.42)\end{array}$ & & $\begin{array}{c}-1.179 * * * \\
(-5.13)\end{array}$ & & $\begin{array}{c}-1.398 * * \\
(-2.50)\end{array}$ \\
\hline ROA (t-1) & & $\begin{array}{l}-0.005 \\
(-0.93)\end{array}$ & & $\begin{array}{l}-0.001 \\
(-0.04)\end{array}$ & & $\begin{array}{l}0.023 \\
(1.10)\end{array}$ & & $\begin{array}{l}-0.010 \\
(-1.46)\end{array}$ & & $\begin{array}{l}-0.004 \\
(-0.44)\end{array}$ \\
\hline OER (t-1) & & $\begin{array}{l}-0.001 \\
(-0.36)\end{array}$ & & $\begin{array}{l}0.005 \\
(1.01)\end{array}$ & & $\begin{array}{c}0.015^{*} \\
(1.83)\end{array}$ & & $\begin{array}{l}-0.003 \\
(-1.19)\end{array}$ & & $\begin{array}{l}-0.002 \\
(-0.41)\end{array}$ \\
\hline CAR $(\mathrm{t}-1)$ & & $\begin{array}{l}0.001 \\
(0.99)\end{array}$ & & $\begin{array}{l}0.003 \\
(0.78)\end{array}$ & & $\begin{array}{l}0.005 \\
(0.89)\end{array}$ & & $\begin{array}{l}0.004 \\
(1.54)\end{array}$ & & $\begin{array}{l}-0.001 \\
(-0.20)\end{array}$ \\
\hline PaR30 (t-1) & & $\begin{array}{c}-0.037 * * * \\
(-7.22)\end{array}$ & & $\begin{array}{l}-0.017 \\
(-1.42)\end{array}$ & & $\begin{array}{l}-0.008 \\
(-0.55)\end{array}$ & & $\begin{array}{c}-0.050 * * * \\
(-5.95)\end{array}$ & & $\begin{array}{c}-0.039 * * * \\
(-5.29)\end{array}$ \\
\hline Regulated (YES) & & $\begin{array}{c}0.212 * * \\
(3.18)\end{array}$ & & $\begin{array}{l}-0.039 \\
(-0.22)\end{array}$ & & $\begin{array}{l}0.306 \\
(1.20)\end{array}$ & & $\begin{array}{c}0.242^{*} \\
(1.86)\end{array}$ & & $\begin{array}{c}0.365^{* *} \\
(3.23)\end{array}$ \\
\hline GDP growth $(\mathrm{t}-1)$ & & $\begin{array}{c}-0.033^{* * *} * \\
(-3.45) \\
\end{array}$ & & $\begin{array}{l}-0.029 \\
(-1.27) \\
\end{array}$ & & $\begin{array}{l}-0.018 \\
(-0.62) \\
\end{array}$ & & $\begin{array}{c}-0.038 * * \\
(-2.54) \\
\end{array}$ & & $\begin{array}{l}-0.039 \\
(-1.64) \\
\end{array}$ \\
\hline Hetero & $-0.060 * * *$ & $-0.039 * * *$ & $-0.020 * * *$ & $-0.022 * * *$ & -0.034 & -0.008 & $-0.087 * * *$ & $-0.038 * * *$ & $-0.075 * * *$ & $-0.072 * * *$ \\
\hline LM test & $54.24 * * *$ & $27.99 * * *$ & $53.59 * * *$ & $15.74 * * *$ & 1.17 & 0.06 & $31.04 * * *$ & $10.93 * * *$ & $39.95 * * *$ & $30.28 * * *$ \\
\hline Observations & 7,920 & 6,941 & 924 & 794 & 1,155 & 962 & 2,835 & 2,533 & 2,997 & 2,652 \\
\hline Region FE & YES & YES & YES & YES & YES & YES & YES & YES & YES & YES \\
\hline Year FE & YES & YES & YES & YES & YES & YES & YES & YES & YES & YES \\
\hline Hansen $\mathbf{J}$ statistic & 24.0 & 16.4 & 21.3 & 18.2 & 24.4 & 27.2 & 34.8 & 25.7 & 20.4 & 24.4 \\
\hline Hansen test $p$-value & 0.20 & 0.63 & 0.32 & 0.51 & 0.14 & 0.08 & 0.02 & 0.14 & 0.37 & 0.18 \\
\hline $\mathrm{AR}(1) p$-value & 0.00 & 0.00 & 0.00 & 0.00 & 0.15 & 0.00 & 0.08 & 0.00 & 0.00 & 0.00 \\
\hline $\mathrm{AR}(2) p$-value & 0.07 & 0.21 & 0.37 & 0.28 & 0.21 & 0.31 & 0.39 & 0.25 & 0.78 & 0.44 \\
\hline Number of instruments & 41 & 49 & 41 & 49 & 40 & 48 & 41 & 49 & 41 & 49 \\
\hline Wald Chi-squared test & $29.2 *$ & $242.1 * * *$ & $102.3 * * *$ & $142.7 * * *$ & $60.5 * * *$ & $83.1 * * *$ & 22.5 & $121.3 * * *$ & 22.9 & $137.9 * * *$ \\
\hline Mean VIF & 3.26 & 2.99 & 2.40 & 2.46 & 4.23 & 3.55 & 3.53 & 3.30 & 3.37 & 3.17 \\
\hline
\end{tabular}

Mean VIF 3.26

$2.40 \quad 2.46$

4.23

3.55

17

reports the estimated coefficient on the lagged squared size variable. The Lagrange Multiplier (LM) test statistic is reported below. AR(1) and AR(2) are tests for first and second-order serial correlation in the first differenced residual. Lagged dependent variable is instrumented by lagged levels dated t -3 (first-differences equation) and by lagged first-differences (levels equation). Lagged control variables (total assets, active borrowers, ROA, OER, CAR, PaR30) are used as instruments for the levels equation only, since they are assumed to be uncorrelated with the contemporaneous error term but become endogenous in first differences. To avoid using an excessive number of instruments, exogenous variables (i.e. age, regulated, lagged GDP growth, regions and year) are used directly as instruments in the level equation. ***,** and * denote significance at the 1,5 and $10 \%$ levels, respectively. 
Table 3. Dynamic panel estimation results (Dependent variable: Growth in borrowers)

\begin{tabular}{|c|c|c|c|c|c|c|c|c|c|c|}
\hline & \multicolumn{2}{|c|}{ All } & \multicolumn{2}{|c|}{ Micro-bank } & \multicolumn{2}{|c|}{ Cooperatives/credit unions } & \multicolumn{2}{|c|}{ NBFI } & \multicolumn{2}{|c|}{ NGO } \\
\hline & Model 1 & Model 2 & Model 1 & Model 2 & Model 1 & Model 2 & Model 1 & Model 2 & Model 1 & Model 2 \\
\hline$\theta: \log ($ Active borrowers $(\mathrm{t}-1))$ & $\begin{array}{l}-0.038 \\
(-0.94)\end{array}$ & $\begin{array}{l}-0.012 \\
(-0.31)\end{array}$ & $\begin{array}{l}-0.050 \\
(-0.52)\end{array}$ & $\begin{array}{l}-0.006 \\
(-0.08)\end{array}$ & $\begin{array}{l}-0.096 \\
(-1.15)\end{array}$ & $\begin{array}{l}-0.031 \\
(-0.39)\end{array}$ & $\begin{array}{l}0.047 \\
(0.69)\end{array}$ & $\begin{array}{l}-0.015 \\
(-0.25)\end{array}$ & $\begin{array}{l}0.045 \\
(0.76)\end{array}$ & $\begin{array}{l}-0.035 \\
(-0.62)\end{array}$ \\
\hline$\rho:$ Growth in borrowers $(\mathrm{t}-1)$ & $\begin{array}{c}0.215^{* *} \\
(2.66)\end{array}$ & $\begin{array}{l}0.022 \\
(0.24)\end{array}$ & $\begin{array}{l}0.256 \\
(1.61)\end{array}$ & $\begin{array}{l}0.138 \\
(0.56)\end{array}$ & $\begin{array}{l}0.148 \\
(0.81)\end{array}$ & $\begin{array}{l}-0.243 \\
(-1.50)\end{array}$ & $\begin{array}{l}0.104 \\
(0.94)\end{array}$ & $\begin{array}{l}0.127 \\
(1.02)\end{array}$ & $\begin{array}{l}0.001 \\
(0.01)\end{array}$ & $\begin{array}{l}0.033 \\
(0.20)\end{array}$ \\
\hline Age: Young & & $\begin{array}{c}-1.886 * * \\
(-2.79)\end{array}$ & & $\begin{array}{l}1.219 \\
(1.04)\end{array}$ & & $\begin{array}{l}-2.511^{*} \\
(-1.81)\end{array}$ & & $\begin{array}{l}-1.459 \\
(-1.61)\end{array}$ & & $\begin{array}{l}-1.804 \\
(-1.55)\end{array}$ \\
\hline Age: Mature & & $\begin{array}{c}-2.294 * * \\
(-3.21)\end{array}$ & & $\begin{array}{l}0.394 \\
(0.29)\end{array}$ & & $\begin{array}{c}-2.953 * * \\
(-1.97)\end{array}$ & & $\begin{array}{c}-1.659^{*} \\
(-1.73)\end{array}$ & & $\begin{array}{c}-2.425^{*} \\
(-1.94)\end{array}$ \\
\hline ROA (t-1) & & $\begin{array}{l}-0.001 \\
(-0.05)\end{array}$ & & $\begin{array}{l}-0.000 \\
(-0.01)\end{array}$ & & $\begin{array}{l}0.037 \\
(0.81)\end{array}$ & & $\begin{array}{l}-0.014 \\
(-0.67)\end{array}$ & & $\begin{array}{l}0.005 \\
(0.37)\end{array}$ \\
\hline OER (t-1) & & $\begin{array}{l}0.006 \\
(1.31)\end{array}$ & & $\begin{array}{l}0.009 \\
(0.56)\end{array}$ & & $\begin{array}{c}0.044 * * \\
(2.58)\end{array}$ & & $\begin{array}{l}0.005 \\
(0.58)\end{array}$ & & $\begin{array}{l}-0.003 \\
(-0.40)\end{array}$ \\
\hline CAR (t-1) & & $\begin{array}{l}0.003 \\
(0.93)\end{array}$ & & $\begin{array}{l}-0.009 \\
(-0.76)\end{array}$ & & $\begin{array}{l}0.001 \\
(0.05)\end{array}$ & & $\begin{array}{l}0.000 \\
(0.04)\end{array}$ & & $\begin{array}{l}0.004 \\
(0.74)\end{array}$ \\
\hline PaR30 (t-1) & & $\begin{array}{c}-0.051 * * * \\
(-5.12)\end{array}$ & & $\begin{array}{l}-0.043 \\
(-1.45)\end{array}$ & & $\begin{array}{c}-0.082 * * \\
(-3.02)\end{array}$ & & $\begin{array}{c}-0.037 * \\
(-1.91)\end{array}$ & & $\begin{array}{c}-0.056^{* * * *} \\
(-3.63)\end{array}$ \\
\hline Regulated (YES) & & $\begin{array}{c}0.505 * * * \\
(3.80)\end{array}$ & & $\begin{array}{l}-0.214 \\
(-0.50)\end{array}$ & & $\begin{array}{l}-0.366 \\
(-0.80)\end{array}$ & & $\begin{array}{l}0.270 \\
(0.98)\end{array}$ & & $\begin{array}{c}0.998 * * * \\
(4.25)\end{array}$ \\
\hline GDP growth (t-1) & & $\begin{array}{c}-0.039 * \\
(-1.90)\end{array}$ & & $\begin{array}{l}-0.010 \\
(-0.22)\end{array}$ & & $\begin{array}{l}-0.093 \\
(-1.27)\end{array}$ & & $\begin{array}{l}-0.010 \\
(-0.32)\end{array}$ & & $\begin{array}{l}-0.050 \\
(-1.41)\end{array}$ \\
\hline Hetero & $-0.372 * * *$ & $-0.300 * * *$ & $-0.224 * * *$ & $\begin{array}{l}-0.126 * * * \\
25.34 * * *\end{array}$ & $-0.453 * * *$ & $\begin{array}{l}-0.292 * * * \\
\end{array}$ & $\begin{array}{l}-0.538 * * * \\
7022 * * *\end{array}$ & $\begin{array}{l}-0.469 * * * \\
0.57 * * *\end{array}$ & $\begin{array}{l}-0.205 * * * \\
1074 * * *\end{array}$ & $-0.165 * * *$ \\
\hline $\begin{array}{l}\text { LM test } \\
\text { Observations }\end{array}$ & $\frac{141.70 * * *}{7.963}$ & $\frac{125.42 * * *}{26.848}$ & $\begin{array}{c}19.17 * * * \\
932\end{array}$ & $\begin{array}{c}25.34 * * * \\
773\end{array}$ & $\begin{array}{c}15.16^{* * *} \\
1.148\end{array}$ & $\frac{16.26^{* * *}}{938}$ & $\frac{79.22 * * *}{2859}$ & $\begin{array}{c}93.51 * * * \\
2515\end{array}$ & $\begin{array}{c}19.74 * * * \\
3.012\end{array}$ & $\frac{12.17 * * *}{2.622}$ \\
\hline $\begin{array}{l}\text { Observations } \\
\text { Region FE }\end{array}$ & YES & $\begin{array}{l}0,040 \\
\text { YES }\end{array}$ & YES & YES & YES & YES & YES & $\begin{array}{l}2,515 \\
\text { YES }\end{array}$ & $\begin{array}{l}3,012 \\
\text { YES }\end{array}$ & $\begin{array}{l}2,622 \\
\text { YES }\end{array}$ \\
\hline Year FE & YES & YES & YES & YES & YES & YES & YES & YES & YES & YES \\
\hline Hansen $\mathrm{J}$ statistic & 27.5 & 25.7 & 19.0 & 18.4 & 21.3 & 14.2 & 19.0 & 22.5 & 20.9 & 15.5 \\
\hline Hansen test $p$-value & 0.10 & 0.14 & 0.46 & 0.49 & 0.27 & 0.72 & 0.46 & 0.26 & 0.34 & 0.69 \\
\hline $\mathrm{AR}(1) p$-value & 0.00 & 0.00 & 0.00 & 0.04 & 0.02 & 0.34 & 0.00 & 0.00 & 0.00 & 0.00 \\
\hline $\mathrm{AR}(2) p$-value & 0.18 & 0.96 & 0.19 & 0.32 & 0.96 & 0.13 & 0.79 & 0.84 & 0.85 & 0.57 \\
\hline Number of instruments & 41 & 49 & 41 & 49 & 40 & 48 & 41 & 49 & 41 & 49 \\
\hline Wald Chi-squared test & $107.2 * * *$ & $223.7 * * *$ & $30.8^{*}$ & $79.2 * * *$ & $76.6 * * *$ & $93.5 * * *$ & $52.0 * * *$ & $147.3 * * *$ & $29.3 * * *$ & $141.7 * * *$ \\
\hline Mean VIF & 3.43 & 3.10 & 2.42 & 2.47 & 4.61 & 3.82 & 3.76 & 3.41 & 3.55 & 3.31 \\
\hline
\end{tabular}

$3.43 \quad 3.10$

4.61

3.82

3.76

Notes: Table 3 reports estimated coefficients from Eq. (4). Z-scores are shown in parentheses below each coefficient estimate. Intercept, time / regional dummies are not reported. 'Hetero'
reports the estimated coefficient on the lagged squared size variable. The Lagrange Multiplier (LM) test statistic is reported below. AR(1) and AR(2) are tests for first and second-order serial correlation in the first differenced residual. Lagged dependent variable is instrumented by lagged levels dated $\mathrm{t}-3$ (first-differences equation) and by lagged first-differences (levels equation). Lagged control variables (total assets, active borrowers, ROA, OER, CAR, PaR30) are used as instruments for the levels equation only, since they are assumed to be uncorrelated with the contemporaneous error term but become endogenous in first differences. To avoid using an excessive number of instruments, exogenous variables (i.e. age, regulated, lagged GDP growth, regions and year) are used directly as instruments in the level equation. $* * * * *$ and $*$ denote significance at the 1,5 and $10 \%$ levels, respectively. 
Table 4. Dynamic panel estimation results by commercial orientation

DV: Growth in assets

\begin{tabular}{|c|c|c|c|c|c|c|c|c|}
\hline & \multicolumn{4}{|c|}{ DV: Growth in assets } & \multicolumn{4}{|c|}{ DV: Growth in borrowers } \\
\hline & \multicolumn{2}{|c|}{ Not-for-profit } & \multicolumn{2}{|c|}{ Profit } & \multicolumn{2}{|c|}{ Not-for-profit } & \multicolumn{2}{|c|}{ Profit } \\
\hline & Model 1 & Model 2 & Model 1 & Model 2 & Model 1 & Model 2 & Model 1 & Model 2 \\
\hline$\overline{\theta \theta} \log ($ Assets (t-1)) & $\begin{array}{l}0.028 \\
(1.53)\end{array}$ & $\begin{array}{l}0.022 \\
(1.40)\end{array}$ & $\begin{array}{l}-0.012 \\
(-0.36)\end{array}$ & $\begin{array}{l}0.025 \\
(0.86)\end{array}$ & & & & \\
\hline$\rho$ : Growth in assets (t-1) & $\begin{array}{c}-0.061^{*} \\
(-1.77)\end{array}$ & $\begin{array}{c}-0.109 * * \\
(-2.15)\end{array}$ & $\begin{array}{l}0.242 \\
(1.44)\end{array}$ & $\begin{array}{l}0.021 \\
(0.12)\end{array}$ & & & & \\
\hline $\log ($ Active borrowers $(\mathrm{t}-1))$ & & & & & $\begin{array}{l}0.037 \\
(0.58)\end{array}$ & $\begin{array}{l}-0.032 \\
(-0.62)\end{array}$ & $\begin{array}{l}-0.055 \\
(-1.01)\end{array}$ & $\begin{array}{l}-0.026 \\
(-0.58)\end{array}$ \\
\hline Growth in borrowers $(\mathrm{t}-1)$ & & & & & $\begin{array}{l}-0.021 \\
(-0.13)\end{array}$ & $\begin{array}{l}0.023 \\
(0.16)\end{array}$ & $\begin{array}{c}0.274 * * \\
(2.42)\end{array}$ & $\begin{array}{l}0.128 \\
(1.16)\end{array}$ \\
\hline Age: Young & & $\begin{array}{c}-1.443 * * * \\
(-5.47)\end{array}$ & & $\begin{array}{l}-0.565 \\
(-1.54)\end{array}$ & & $\begin{array}{l}-1.504 \\
(-1.39)\end{array}$ & & $\begin{array}{l}-1.104 \\
(-1.47)\end{array}$ \\
\hline Age: Mature & & $\begin{array}{c}-1.605 * * * \\
(-5.79)\end{array}$ & & $\begin{array}{c}-0.908^{*} \\
(-1.89)\end{array}$ & & $\begin{array}{c}-1.895^{*} \\
(-1.73)\end{array}$ & & $\begin{array}{c}-1.415^{*} \\
(-1.71)\end{array}$ \\
\hline ROA (t-1) & & $\begin{array}{l}0.001 \\
(0.20)\end{array}$ & & $\begin{array}{l}-0.008 \\
(-1.40)\end{array}$ & & $\begin{array}{l}0.018 \\
(1.22)\end{array}$ & & $\begin{array}{l}-0.022 \\
(-1.22)\end{array}$ \\
\hline OER (t-1) & & $\begin{array}{l}0.004 \\
(1.41)\end{array}$ & & $\begin{array}{l}-0.002 \\
(-1.11)\end{array}$ & & $\begin{array}{l}0.007 \\
(1.00)\end{array}$ & & $\begin{array}{l}0.003 \\
(0.62)\end{array}$ \\
\hline CAR (t-1) & & $\begin{array}{l}-0.001 \\
(-0.39)\end{array}$ & & $\begin{array}{c}0.006 * * \\
(2.56)\end{array}$ & & $\begin{array}{l}0.003 \\
(0.61)\end{array}$ & & $\begin{array}{l}0.001 \\
(0.26)\end{array}$ \\
\hline PaR30 (t-1) & & $\begin{array}{c}-0.036 * * * \\
(-6.46)\end{array}$ & & $\begin{array}{c}-0.041 * * \\
(-3.17)\end{array}$ & & $\begin{array}{c}-0.057 * * * \\
(-3.97)\end{array}$ & & $\begin{array}{c}-0.029^{*} \\
(-1.82)\end{array}$ \\
\hline GDP growth (t-1) & & $\begin{array}{c}-0.031^{* *} \\
(-2.36) \\
\end{array}$ & & $\begin{array}{c}-0.029 * * \\
(-1.98) \\
\end{array}$ & & $\begin{array}{c}-0.063^{*} \\
(-1.89) \\
\end{array}$ & & $\begin{array}{l}-0.008 \\
(-0.31) \\
\end{array}$ \\
\hline $\begin{array}{l}\text { Hetero } \\
\text { LM test }\end{array}$ & $\begin{array}{l}-0.058 * * * \\
18.43 * * * *\end{array}$ & $\begin{array}{l}-0.036 * * \\
7.54 * * *\end{array}$ & $\begin{array}{l}-0.041 * * * \\
107.41 * * *\end{array}$ & $\begin{array}{l}-0.029 * * * \\
105.84 * * *\end{array}$ & $\begin{array}{l}-0.319 * * * \\
58.46 * * * *\end{array}$ & $\begin{array}{l}-0.240 * * * * \\
43.89 * * *\end{array}$ & $\begin{array}{l}-0.458 * * * \\
84.36 * * * *\end{array}$ & $\begin{array}{l}-0.402 * * * \\
97.17 * * *\end{array}$ \\
\hline Observations & 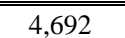 & 4,155 & 3,113 & 2,741 & 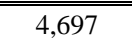 & 4 & 3,129 & 2,695 \\
\hline Region FE & YES & YES & YES & YES & YES & YES & YES & YES \\
\hline Year FE & YES & YES & YES & YES & YES & YES & YES & YES \\
\hline Hansen $\mathrm{J}$ statistic & 23.9 & 17.2 & 30.7 & 24.5 & 26.6 & 24.2 & 25.8 & 25.2 \\
\hline Hansen test $p$-value & 0.20 & 0.57 & 0.043 & 0.18 & 0.11 & 0.19 & 0.13 & 0.15 \\
\hline $\mathrm{AR}(1) p$-value & 0.03 & 0.00 & 0.00 & 0.01 & 0.01 & 0.00 & 0.00 & 0.00 \\
\hline $\mathrm{AR}(2) p$-value & 0.16 & 0.15 & 0.34 & 0.77 & 0.85 & 0.78 & 0.49 & 0.98 \\
\hline Number of instruments & 41 & 49 & 41 & 49 & 41 & 49 & 41 & 49 \\
\hline Wald Chi-squared test & 25.2 & $158.6 * * *$ & $35.7 * *$ & $141.5^{* * *}$ & $41.0^{* * * *}$ & $114.4 * * *$ & $52.0 * * *$ & $258.0^{* * *}$ \\
\hline Mean VIF & 3.43 & 3.13 & 3.07 & 2.90 & 3.58 & 3.26 & 3.22 & 2.97 \\
\hline
\end{tabular}

Notes: Table 4 reports estimated coefficients from Eq. (4). Z-scores are shown in parentheses below each coefficient estimate. Intercept, time / regional dummies are not reported. 'Hetero' reports the estimated coefficient on the lagged squared size variable. The Lagrange Multiplier (LM) test statistic is reported below. AR(1) and AR(2) are tests for first and second-order serial correlation in the first differenced residual. Lagged dependent variable is instrumented by lagged levels dated $t-3$ (first-differences equation) and by lagged first-differences (levels equation). Lagged control variables (i.e. total assets, active borrowers, ROA, OER, CAR, PaR30) are used as instruments for the levels equation only, since they are assumed to be uncorrelated with the contemporaneous error term but become endogenous in first differences. To avoid using an excessive number of instruments, exogenous variables (i.e. age, regulated, lagged GDP growth, regions and year) are used directly as instruments in the level equation. ***,** and * denote significance at the 1,5 and $10 \%$ levels, respectively. 
Table 5. Key hypotheses and results for multivariate models

\begin{tabular}{|c|c|c|c|c|c|c|c|}
\hline Tests for growth in assets & ALL & Micro-bank & $\begin{array}{l}\text { Cooperatives / } \\
\text { credit unions }\end{array}$ & NBFI & NGO & Not-for-profit & Profit \\
\hline $\begin{array}{l}\text { MFI growth is independent of } \\
\text { size }\end{array}$ & Cannot reject & Cannot reject & Cannot reject & Cannot reject & Cannot reject & Cannot reject & Cannot reject \\
\hline MFI growth is not persistent & Cannot reject & Cannot reject & $\begin{array}{c}\text { Rejected } \\
\text { (negative sign) }\end{array}$ & Cannot reject & Cannot reject & $\begin{array}{c}\text { Rejected } \\
\text { (negative sign) }\end{array}$ & Cannot reject \\
\hline $\begin{array}{l}\text { MFI growth variability is } \\
\text { independent of size }\end{array}$ & $\begin{array}{c}\text { Rejected } \\
\text { (negative sign) }\end{array}$ & $\begin{array}{c}\text { Rejected } \\
\text { (negative sign) }\end{array}$ & Cannot reject & $\begin{array}{c}\text { Rejected } \\
\text { (negative sign) }\end{array}$ & $\begin{array}{c}\text { Rejected } \\
\text { (negative sign) }\end{array}$ & $\begin{array}{c}\text { Rejected } \\
\text { (negative sign) }\end{array}$ & $\begin{array}{c}\text { Rejected } \\
\text { (negative sign) }\end{array}$ \\
\hline
\end{tabular}

\begin{tabular}{|c|c|c|c|c|c|c|c|}
\hline $\begin{array}{l}\text { Tests for growth in } \\
\text { borrowers }\end{array}$ & ALL & Micro-bank & $\begin{array}{l}\text { Cooperatives / } \\
\text { credit unions }\end{array}$ & NBFI & NGO & Not-for-profit & Profit \\
\hline $\begin{array}{l}\text { Borrowers growth is } \\
\text { independent of size }\end{array}$ & Cannot reject & Cannot reject & Cannot reject & Cannot reject & Cannot reject & Cannot reject & Cannot reject \\
\hline $\begin{array}{l}\text { Borrowers growth is not } \\
\text { persistent }\end{array}$ & Cannot reject & Cannot reject & Cannot reject & Cannot reject & Cannot reject & Cannot reject & Cannot reject \\
\hline $\begin{array}{l}\text { Borrowers growth variability } \\
\text { is independent of size }\end{array}$ & $\begin{array}{c}\text { Rejected } \\
\text { (negative sign) }\end{array}$ & $\begin{array}{c}\text { Rejected } \\
\text { (negative sign) }\end{array}$ & $\begin{array}{c}\text { Rejected } \\
\text { (negative sign) }\end{array}$ & $\begin{array}{c}\text { Rejected } \\
\text { (negative sign) }\end{array}$ & $\begin{array}{c}\text { Rejected } \\
\text { (negative sign) }\end{array}$ & $\begin{array}{c}\text { Rejected } \\
\text { (negative sign) }\end{array}$ & $\begin{array}{c}\text { Rejected } \\
\text { (negative sign) }\end{array}$ \\
\hline
\end{tabular}

Note: All conclusions are drawn using the full model (Model 2) and a 5\% and $1 \%$ level of significance. 
Table A1. Number of Microfinance Institutions (MFIs) by country (Panel A) and year (Panel B)

Panel A

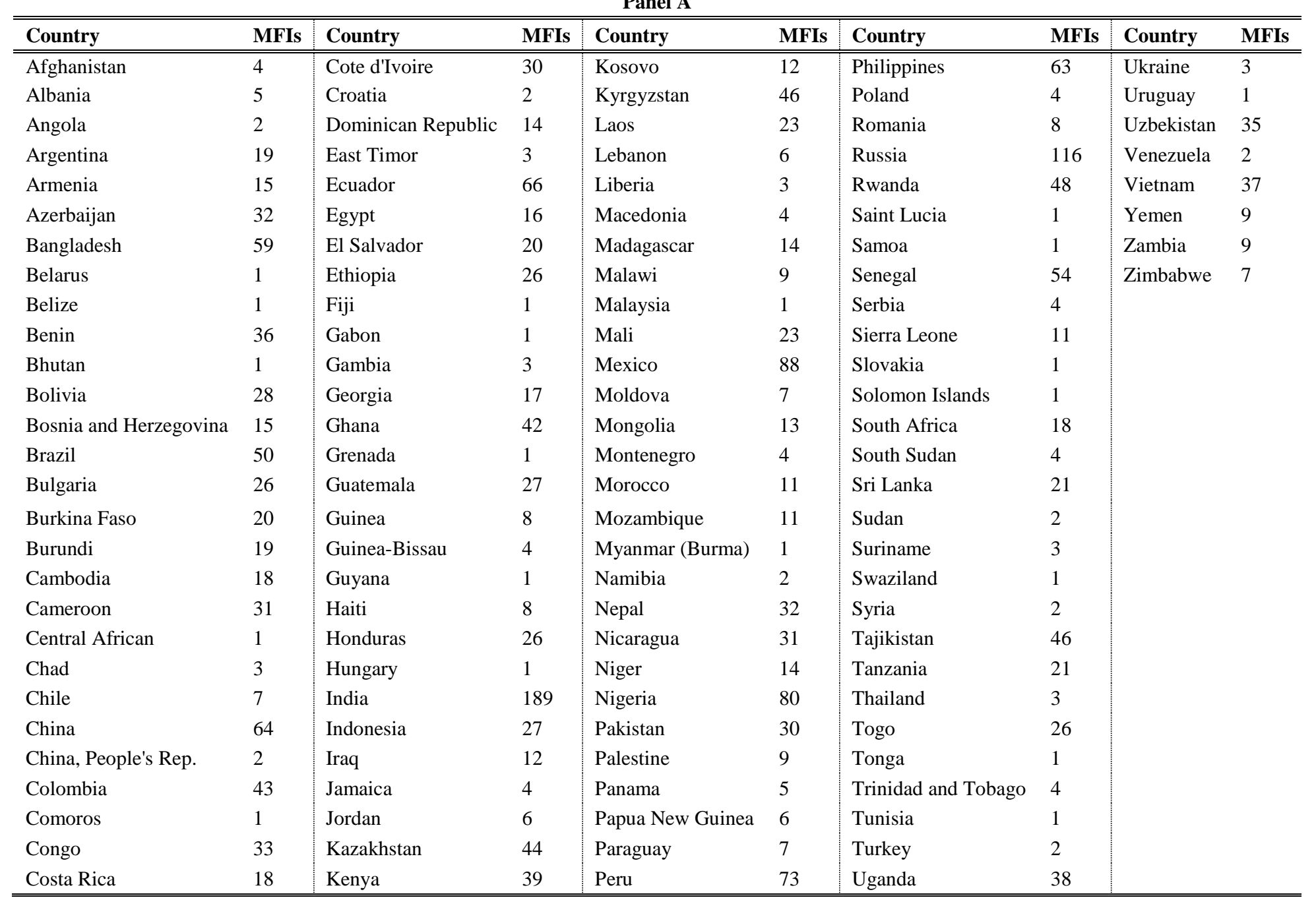

Panel B

\begin{tabular}{cc}
\multicolumn{2}{c}{ Panel B } \\
\hline \hline Year & MFIs \\
\hline \hline 2000 & 204 \\
2001 & 311 \\
2002 & 484 \\
2003 & 692 \\
2004 & 859 \\
2005 & 1015 \\
2006 & 1104 \\
2007 & 1121 \\
2008 & 1255 \\
2009 & 1319 \\
2010 & 1342 \\
2011 & 1396 \\
2012 & 1135 \\
2013 & 708 \\
2014 & 421 \\
\hline \hline
\end{tabular}


Table A2. Pairwise Pearson correlation matrix

(1)

(2)

(3)

(4)

(5)

(6)

(7)

(8)

(9)

(10)

\begin{tabular}{|c|c|c|c|c|c|c|c|c|c|c|c|}
\hline Growth in assets & (1) & 1 & & & & & & & & & \\
\hline Growth in borrowers & $(2)$ & $0.5302 * * *$ & 1 & & & & & & & & \\
\hline $\log ($ Size $)$ & (3) & $-0.1062 * * *$ & $-0.1340 * * *$ & 1 & & & & & & & \\
\hline $\log$ (Active borrowers) & $(4)$ & $-0.0819 * * *$ & $-0.0899 * * *$ & $0.7647 * * *$ & 1 & & & & & & \\
\hline Age & $(5)$ & $-0.2808 * * *$ & $-0.3126 * * *$ & $0.3860 * * *$ & $0.3566 * * *$ & 1 & & & & & \\
\hline ROA & $(6)$ & -0.0107 & $-0.0759 * * *$ & $0.1781 * * *$ & $0.1250 * * *$ & $0.1467 * * *$ & 1 & & & & \\
\hline OER & (7) & $0.0644 * * *$ & $0.1292 * * *$ & $-0.2976 * * *$ & $-0.1664 * * *$ & $-0.2299 * * *$ & $-0.5776^{* * *}$ & 1 & & & \\
\hline CAR & (8) & $-0.0263 * * *$ & 0.0163 & $-0.2854 * * *$ & $-0.2517 * * *$ & $-0.1672 * * *$ & $0.0887 * * *$ & $0.1771 * * *$ & 1 & & \\
\hline PaR30 & $(9)$ & $-0.2140 * * *$ & $-0.1482 * * *$ & $-0.0553 * * *$ & $-0.0900 * * *$ & $0.0616^{* * *}$ & $-0.2235^{* * *}$ & $0.0832 * * *$ & -0.0065 & 1 & \\
\hline GDP growth & (10) & $0.1571 * * *$ & $0.1019 * * *$ & $-0.0625 * * *$ & 0.0046 & $-0.1133 * * *$ & $0.0626 * * *$ & $-0.0717 * * *$ & $0.0296^{* * *}$ & $-0.1206^{* * *}$ & 1 \\
\hline
\end{tabular}

Notes: The reported pairwise Pearson correlations are for the panel data set (2000-2014).***,** and * denote significance at the 1, 5 and $10 \%$ levels, respectively. 
Table A3. Dynamic panel estimation results using restricted samples (Dependent variable: growth in assets)

\begin{tabular}{|c|c|c|c|c|c|c|}
\hline & \multicolumn{2}{|c|}{ Restricted sample: $\mathbf{t} \geq 9$} & \multicolumn{2}{|c|}{ Restricted sample: $i \geq 36$} & \multicolumn{2}{|c|}{ Restricted sample: $t \geq 9 \& i \geq 3$} \\
\hline & "Model 1 & Model 2 & Model 1 & Model 2 & Model 1 & Model 2 \\
\hline$\theta: \log ($ Assets $(t-1))$ & $\begin{array}{l}0.013 \\
(0.59)\end{array}$ & $\begin{array}{l}0.029 \\
(1.45)\end{array}$ & $\begin{array}{l}-0.024 \\
(-1.12)\end{array}$ & $\begin{array}{l}0.002 \\
(0.10)\end{array}$ & $\begin{array}{l}-0.008 \\
(-0.32)\end{array}$ & $\begin{array}{l}0.012 \\
(0.46)\end{array}$ \\
\hline$\rho:$ Growth in assets $(\mathrm{t}-1)$ & $\begin{array}{l}0.155 \\
(1.07)\end{array}$ & $\begin{array}{l}-0.109 \\
(-0.88)\end{array}$ & $\begin{array}{c}0.171 * * \\
(2.07)\end{array}$ & $\begin{array}{l}0.036 \\
(0.26)\end{array}$ & $\begin{array}{c}0.333^{*} * \\
(2.31)\end{array}$ & $\begin{array}{l}0.150 \\
(0.78)\end{array}$ \\
\hline Age: Young & & $\begin{array}{c}-0.824 * * \\
(-2.58)\end{array}$ & & $\begin{array}{c}-1.153 * * \\
(-2.65)\end{array}$ & & $\begin{array}{l}-0.889 \\
(-1.59)\end{array}$ \\
\hline Age: Mature & & $\begin{array}{c}-1.145^{* *} \\
(-3.12)\end{array}$ & & $\begin{array}{c}-1.404 * * \\
(-2.76)\end{array}$ & & $\begin{array}{c}-1.166^{*} \\
(-1.73)\end{array}$ \\
\hline ROA (t-1) & & $\begin{array}{l}0.002 \\
(0.36)\end{array}$ & & $\begin{array}{l}-0.000 \\
(-0.01)\end{array}$ & & $\begin{array}{l}0.009 \\
(0.93)\end{array}$ \\
\hline OER (t-1) & & $\begin{array}{l}0.000 \\
(0.15)\end{array}$ & & $\begin{array}{l}0.001 \\
(0.25)\end{array}$ & & $\begin{array}{l}0.001 \\
(0.53)\end{array}$ \\
\hline CAR (t-1) & & $\begin{array}{l}0.001 \\
(0.39)\end{array}$ & & $\begin{array}{l}-0.002 \\
(-0.65)\end{array}$ & & $\begin{array}{l}0.001 \\
(0.52)\end{array}$ \\
\hline PaR30 (t-1) & & $\begin{array}{c}-0.036 * * * \\
(-5.31)\end{array}$ & & $\begin{array}{c}-0.037 * * * \\
(-3.38)\end{array}$ & & $\begin{array}{c}-0.021 * * \\
(-2.21)\end{array}$ \\
\hline Regulated (YES) & & $\begin{array}{c}0.191 * * \\
(2.78)\end{array}$ & & $\begin{array}{c}0.211 * * \\
(2.04)\end{array}$ & & $\begin{array}{c}0.290 * * * \\
(3.46)\end{array}$ \\
\hline GDP growth (t-1) & & $\begin{array}{c}-0.024 * * \\
(-2.45) \\
\end{array}$ & & $\begin{array}{l}-0.011 \\
(-0.72) \\
\end{array}$ & & $\begin{array}{l}0.005 \\
(0.29) \\
\end{array}$ \\
\hline Hetero & $-0.022 * * *$ & $-0.022 * * *$ & $-0.070 * * *$ & $-0.054 * * *$ & $-0.026 * * *$ & $-0.024 * * *$ \\
\hline LM test & $71.72 * * *$ & $82.86^{* * *}$ & $30.16^{* * *}$ & $18.77 * * *$ & $33.78 * * *$ & $32.35 * * *$ \\
\hline Observations & ב5,223 & 4 & 3,852 & 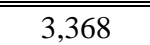 & 2,310 & 2,150 \\
\hline Region FE & YES & YES & YES & YES & YES & YES \\
\hline Year FE & YES & YES & YES & YES & YES & YES \\
\hline Hansen J statistic & 26.0 & 23.0 & 23.9 & 20.3 & 22.7 & 22.5 \\
\hline Hansen test $p$-value & 0.13 & 0.24 & 0.20 & 0.38 & 0.25 & 0.26 \\
\hline $\mathrm{AR}(1) p$-value & 0.00 & 0.00 & 0.01 & 0.00 & 0.00 & 0.01 \\
\hline $\mathrm{AR}(2) p$-value & 0.32 & 0.19 & 0.058 & 0.69 & 0.087 & 0.68 \\
\hline Number of instruments & 41 & 49 & 40 & 48 & 40 & 48 \\
\hline Wald Chi-squared test & $34.9 *$ & $167.2 * * *$ & 24.0 & $162.7 * * *$ & $46.4 * * *$ & $166.8 * * *$ \\
\hline Mean VIF & 2.80 & 2.80 & 3.46 & 3.07 & 2.75 & 2.71 \\
\hline
\end{tabular}


uncorrelated with the contemporaneous error term but become endogenous in first differences. To avoid using an excessive number of instruments, exogenous variables (i.e. age, regulated, lagged GDP growth, regions and year) are used directly as 1,5 and $10 \%$ levels, respectively.

Table A4. Dynamic panel estimation results using restricted samples (Dependent variable: Growth in borrowers)

\begin{tabular}{|c|c|c|c|c|c|c|}
\hline & \multicolumn{2}{|c|}{ Restricted sample: $t \geq 9$} & \multicolumn{2}{|c|}{ Restricted sample: $i \geq 36$} & \multicolumn{2}{|c|}{ Restricted sample: $\mathbf{t} \geq 9 \& \mathbf{i} \geq \mathbf{3}$} \\
\hline & Model 1 & Model 2 & Model 1 & Model 2 & Model 1 & Model 2 \\
\hline " $\theta: \log ($ Active borrowers $(\mathrm{t}-1))$ & $\begin{array}{l}-0.038 \\
(-1.24)\end{array}$ & $\begin{array}{l}-0.024 \\
(-0.72)\end{array}$ & $\begin{array}{l}-0.078 \\
(-1.57)\end{array}$ & $\begin{array}{l}-0.038 \\
(-0.63)\end{array}$ & $\begin{array}{l}-0.039 \\
(-1.22)\end{array}$ & $\begin{array}{l}-0.031 \\
(-0.72)\end{array}$ \\
\hline$\rho$ : Growth in borrowers $(\mathrm{t}-1)$ & $\begin{array}{c}0.189 * * * \\
(3.30)\end{array}$ & $\begin{array}{l}0.090 \\
(1.22)\end{array}$ & $\begin{array}{c}0.315 * * * \\
(3.70)\end{array}$ & $\begin{array}{l}0.150 \\
(1.05)\end{array}$ & $\begin{array}{c}0.271 * * * \\
(4.73)\end{array}$ & $\begin{array}{l}0.137 \\
(1.10)\end{array}$ \\
\hline Age: Young & & $\begin{array}{c}-1.143 * * \\
(-2.02)\end{array}$ & & $\begin{array}{l}-1.797 \\
(-1.44)\end{array}$ & & $\begin{array}{c}-2.254 * * \\
(-1.99)\end{array}$ \\
\hline Age: Mature & & $\begin{array}{c}-1.709 * * \\
(-2.80)\end{array}$ & & $\begin{array}{l}-2.105 \\
(-1.54)\end{array}$ & & $\begin{array}{c}-2.607 * * \\
(-2.07)\end{array}$ \\
\hline ROA $(\mathrm{t}-1)$ & & $\begin{array}{l}-0.011 \\
(-1.04)\end{array}$ & & $\begin{array}{l}0.011 \\
(0.77)\end{array}$ & & $\begin{array}{l}0.014 \\
(1.01)\end{array}$ \\
\hline OER $(\mathrm{t}-1)$ & & $\begin{array}{l}0.001 \\
(0.22)\end{array}$ & & $\begin{array}{l}0.012 \\
(1.64)\end{array}$ & & $\begin{array}{c}0.011^{*} \\
(1.92)\end{array}$ \\
\hline CAR $(\mathrm{t}-1)$ & & $\begin{array}{l}0.005 \\
(1.39)\end{array}$ & & $\begin{array}{l}0.000 \\
(0.05)\end{array}$ & & $\begin{array}{l}-0.006 \\
(-1.20)\end{array}$ \\
\hline $\operatorname{PaR} 30(\mathrm{t}-1)$ & & $\begin{array}{c}-0.042 * * * \\
(-4.12)\end{array}$ & & $\begin{array}{c}-0.038 * * \\
(-2.54)\end{array}$ & & $\begin{array}{l}-0.023 \\
(-1.55)\end{array}$ \\
\hline Regulated (YES) & & $\begin{array}{c}0.480 * * * \\
(3.34)\end{array}$ & & $\begin{array}{c}0.510 * * \\
(2.71)\end{array}$ & & $\begin{array}{l}0.195 \\
(0.97)\end{array}$ \\
\hline GDP growth (t-1) & & $\begin{array}{l}0.002 \\
(0.09) \\
\end{array}$ & & $\begin{array}{l}-0.000 \\
(-0.00) \\
\end{array}$ & & $\begin{array}{l}0.005 \\
(0.15) \\
\end{array}$ \\
\hline $\begin{array}{l}\text { Hetero } \\
\text { LM test }\end{array}$ & $\begin{array}{c}-0.204 * * * \\
61.66 * * *\end{array}$ & $\begin{array}{l}-0.185 * * * \\
45.92 * * *\end{array}$ & $\begin{array}{l}-0.348 * * * \\
117.41 * * *\end{array}$ & $\begin{array}{l}-0.291 * * * \\
87.11 * * *\end{array}$ & $\begin{array}{l}-0.158 * * * \\
64.82 * * *\end{array}$ & $\begin{array}{l}-0.136 * * * \\
42.38 * * * \\
\end{array}$ \\
\hline Observations & 25,226 & 4,776 & 3,907 & 3,326 & 2,314 & 2,134 \\
\hline Region FE & YES & YES & YES & YES & YES & YES \\
\hline Year FE & YES & YES & YES & YES & YES & YES \\
\hline Hansen J statistic & 21.3 & 20.1 & 22.0 & 21.2 & 18.2 & 23.6 \\
\hline Hansen test $p$-value & 0.32 & 0.39 & 0.29 & 0.33 & 0.51 & 0.21 \\
\hline $\mathrm{AR}(1) p$-value & 0.00 & 0.00 & 0.00 & 0.00 & 0.00 & 0.00 \\
\hline $\mathrm{AR}(2) p$-value & 0.14 & 0.33 & 0.016 & 0.27 & 0.03 & 0.15 \\
\hline Number of instruments & 41 & 49 & 40 & 48 & 40 & 48 \\
\hline Wald Chi-squared test & $84.4 * * *$ & $150.2 * * *$ & $83.0 * * *$ & $309.5 * * *$ & $110.4 * * *$ & $201.2 * * *$ \\
\hline Mean VIF & 2.90 & 2.87 & 3.64 & 3.22 & 2.87 & 2.83 \\
\hline
\end{tabular}

Notes: Table A4 reports estimated coefficients from Eq. (4). Z-scores are shown in parentheses below each coefficient estimate. Intercept, time / regional dummies are not reported. 'Hetero' reports the estimated coefficient on the lagged squared size variable. The Lagrange Multiplier (LM) test statistic is reported below. AR(1) and AR(2) are tests for first and second-order serial correlation in the first differenced residual. Lagged dependent variable is instrumented by lagged levels dated t-3 (first-differences equation) and by lagged first-differences (levels equation). Lagged control variables (total assets, active borrowers, ROA, OER, CAR, PaR30) are used as instruments for the levels equation only, since they are assumed to be 
uncorrelated with the contemporaneous error term but become endogenous in first differences. To avoid using an excessive number of instruments, exogenous variables (i.e. age, regulated, lagged GDP growth, regions and year) are used directly as instruments in the level equation. $* * *, * *$ and $*$ denote significance at the 1,5 and $10 \%$ levels, respectively. 
Table A5. Dynamic panel model including disclosure level as endogenous variable

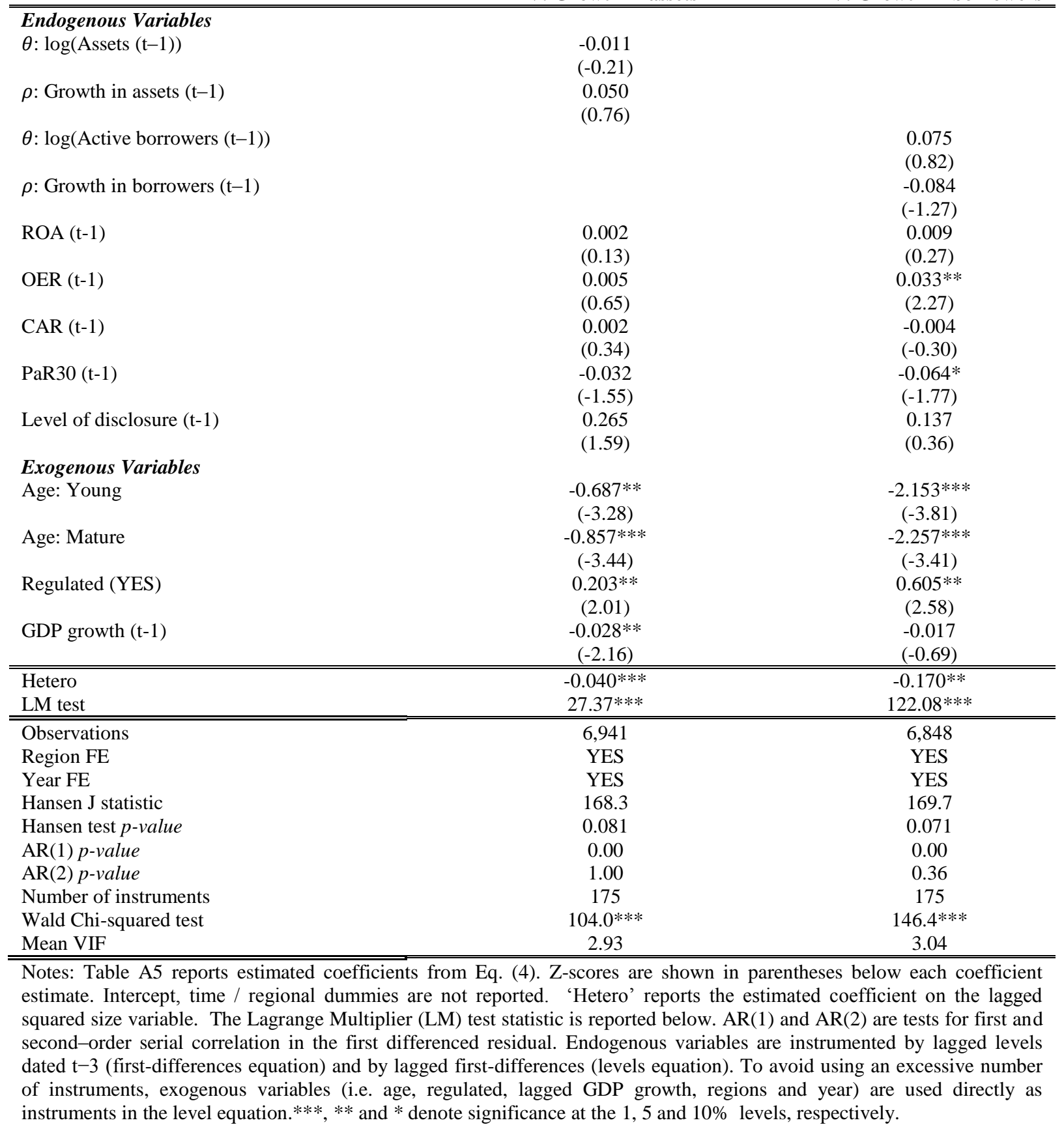

